\title{
Hair-on-end appearance in a case of thalassemia intermedia
}

\author{
Riya Balikar, Neelam Narendra Redkar, Meenakshi Amit Patil, Rajit Pillai
}

Department of Medicine, Seth GS Medical College and KEM Hospital, Mumbai, Maharashtra, India

\section{Correspondence to}

Dr Meenakshi Amit Patil, meenakshi.patil90@gmail.com
To cite: Balikar $\mathrm{R}$ Redkar NN, Patil MA, et al. BMJ Case Reports Published online: [please include Day Month Year] doi:10.1136/ bcr-2012-008095

\section{DESCRIPTION}

The hair-on-end sign is a finding seen in the diploic space on skull radiographs and has the appearance of long, thin vertical striations of calcified spicules perpendicular to bone surface that look like hair standing on end. It is classically seen in children/ adolescents with haemolytic anaemias, in particular, thalassemia major.

A 24-year-oldman, born out of consanguinous marriage with history of splenectomy done at the age of four and history of requiring frequent blood transfusions, that is, every 5-6 months, came with complaints of breathlessness on exertion, generalised fatiguability and weakness. On examination the patient had frontal bossing, haemolytic facies and hepatomegaly. His haemoglobin $(\mathrm{Hb})$ was $5.6 \mathrm{~g} / \mathrm{dl}$ and peripheral smear revealed hypochromic, microcytic red blood cells with target cells. Serum iron studies revealed serum iron of $300 \mathrm{mg} / \mathrm{dl}(200-400 \mathrm{mg} / \mathrm{dl})$ and serum ferritin of $1500 \mathrm{ng} / \mathrm{ml}(20-300 \mathrm{ng} / \mathrm{ml})$. Haemoglobin electrophoresis showed fetal haemoglobin $\mathrm{F}$ of $7 \mathrm{~g} / \mathrm{dl}$ and adult haemoglobin $\mathrm{A}$ of $8.8 \mathrm{~g} / \mathrm{dl}$. A skeletal survey was done which revealed evidence of extra medullary haematopoiesis with a classical hair-on-end appearance seen on $\mathrm{x}$-ray skull (figures 1 and 2). The patient was given three packed cell transfusions. The patient was advised tablet folic acid daily and iron chelation therapy. The patient was discharged on a $\mathrm{Hb}$ of $9 \mathrm{~g} / \mathrm{dl}$.

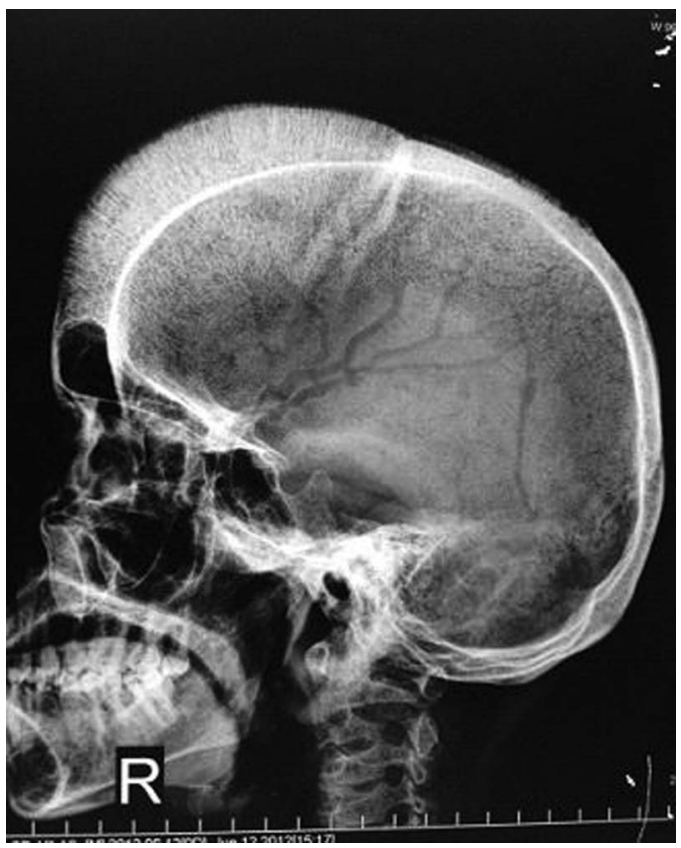

Figure 1 Hair-on-end appearance-lateral view.

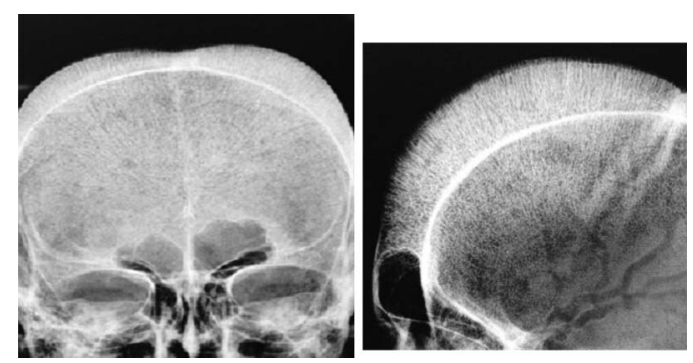

Figure 2 Hair-on-end appearance-frontal view.

Cooley and Lee described skeletal changes associated with haemolytic anaemias, more than 80 years ago. ${ }^{1}$ Hair-on-end appearance refers to the skull abnormalities seen predominantly in patients with haemolytic anaemias that is, thalassemia, major, sickle cell anaemia, pyruvate kinase deficiency-hereditary elliptocytosis and spherocytosis. ${ }^{2}$ It is due to periosteal reaction with neo-osteogenesis of the outer cranial table which results in marked calvarial thickening, external displacement and thinning of the inner table. The changes are due to marrow hyperplasia. Hair-on-end appearance is also seen in congenital syphilis-syphilitic periostitis of tibia, metastatic neuroblastoma, iron-deficiency anaemia, cyanoticright-to-left shunt-congenital heart disease, osteomyelitis, polycythaemia vera, thyroid acropachy and haemangiomas. ${ }^{34}$

It is debatable whether the hair-on-end sign may be reversed following treatment of anaemia. The classical presentation is rarely seen these days. Hair-on-end is uncommon in the milder thalassemia intermedia. Similar appearance in facial bones is rare and suggests an extreme degree of medullary erythropoiesis. Our patient had facial involvement as well.

\section{Learning points}

- Hair-on-end appearance refers to the skull abnormalities seen predominantly in patients with haemolytic anaemia and suggests an extreme degree of medullary erythropoiesis and marrow hyperplasia.

- This classical presentation is rare now-a-days.

Contributors RB, NNR, MAP and RP were involved in investigating and managing the patient. MAP was involved in editing the contents of this article. All authors have contributed to the contents of this article.

Competing interests None.

Patient consent Obtained.

Provenance and peer review Not commissioned; externally pee reviewed. 


\section{REFERENCES}

1 Cooley TB, Lee P. A series of cases of anemia with splenomegaly and peculiar bone changes. Trans Am Pediatr Soc 1925;37:29-30.

2 Wisetsin S. Cephalography in thalassemic patients. J Dent Assoc Thai $1990 ; 40: 260-8$
3 Britton HA, Canby JP, Kohler CM. Iron deficiency anemia producing evidence of marrow hyperplasia in the calvarium. Pediatrics 1960;25:621-8.

4 Walor DM, Berdon WE, Westra SJ. 'Hair-on-end' skull changes resembling thalassemia caused by marrow expansion in uncorrected complex cyanotic heart disease. Pediatr Radiol 2005;35:698-701.

Copyright 2013 BMJ Publishing Group. All rights reserved. For permission to reuse any of this content visit http://group.bmj.com/group/rights-licensing/permissions.

BMJ Case Report Fellows may re-use this article for personal use and teaching without any further permission.

Become a Fellow of BMJ Case Reports today and you can:

- Submit as many cases as you like

- Enjoy fast sympathetic peer review and rapid publication of accepted articles

- Access all the published articles

- Re-use any of the published material for personal use and teaching without further permission

For information on Institutional Fellowships contact consortiasales@bmjgroup.com

Visit casereports.bmj.com for more articles like this and to become a Fellow 